Psychometric profile of children with auditory processing disorder and children with dyslexia. Dawes P, Bishop DV (Arch Dis Child 2010;95:432-436). This article was published with an incorrect doi, the correct doi is 10.1136/adc.2009.170118. 
Psychometric profile of children with auditory processing disorder and children with dyslexia. Dawes P, Bishop DV (Arch Dis Child 2010;95:432-436). This article was published with an incorrect doi, the correct doi is 10.1136/adc.2009.170118. 


\section{ADC Corrections}

Arch Dis Child 2011 96: e1 originally published online April 19, 2010 doi: 10.1136/adc.2010.170118

Updated information and services can be found at:

http://adc.bmj.com/content/96/6/e1.6.full.html

\section{These include:}

Email alerting

Receive free email alerts when new articles cite this article. Sign up in service the box at the top right corner of the online article.

Notes

To request permissions go to:

http://group.bmj.com/group/rights-licensing/permissions

To order reprints go to:

http://journals.bmj.com/cgi/reprintform

To subscribe to BMJ go to:

http://group.bmj.com/subscribe/ 